\title{
THE USE OF LAPTOP COMPUTERS, TABLETS AND GOOGLE EARTH/GOOGLE MAPS APPLICATIONS DURING GEOGRAPHY CLUB SEMINARS
}

\author{
FLORIN GALBIN \\ "Radu Petrescu" High School, Prundu Bîrgăului, Bistriţa-Năsăud County, Romania, e-mail: florin_galbin@yahoo.com
}

(Received: January 2015; in revised form: February 2015)

\begin{abstract}
In the current study, we aim to investigate the use of Google Earth and Google Maps Applications on tablet and laptop computers. The research was carried out during the Geography Club seminars organized at "Radu Petrescu" High School in the 2013-2014 school year. The research involved 13 students in various gymnasium and high school grades. The activities included: navigation with Google Earth/Maps, image capturing techniques, virtual tours, measuring distances or river lengths, identifying relief forms, and locating geographical components of the environment. In order to retrieve students' opinions regarding the use of tablets and laptop computers with these two applications, they were asked to respond to a questionnaire after the activities took place. Conclusions revealed that students enjoyed using these applications with laptops and tablets and that the learning process during Geography classes became more interesting.
\end{abstract}

Keywords: virtual tour, e-learning, Geography Club seminar, electronic portfolio, virtual lesson

\section{INTRODUCTION}

Following Romania's admission into the European Union, Art. 68 of the Law on National Education (2011) in Romania specifies the key competences that any student should display as he or she undergoes mandatory education cycles. "The national curriculum for primary and secondary education emphasizes 8 key-competence domains which determine the profile and formation of any student." Two of these domains are: "basic mathematical, science and technology skills" and "digital skills in the use of information technology as a learning and knowledge tool". Two main 
reasons justifying the creation of these competences are the following: "education and professional development of children, young adults and adults aim at developing skills as a multifunctional and transferable assembly of knowledge, skills, abilities that are necessary for personal development and fulfilment, social integration and active societal participation" (2011, Art. 4).

There are also relevant studies about the use and advantages of tablets and laptops in education (Smith, Valliappa, 2006; Whitmeyer, 2012; Fabian, Maclean, 2014), about the role of digital literacy (Hall, Atkins, Fraser, 2014) and of geographical literacy (Thomas-Brown, 2011; Chou, Block, Jesness, 2012) in achieving the objectives of geographical education, as well as more focused studies on Google Earth as a resource (Lisle, 2006) and as more than a Geography education tool (Patterson, 2007) and its usefulness in interpreting geographical phenomena, alongside satellite imagery (Sato, Harp, 2009), and in landscape visualisation (Sheppard, Cizek, 2009).

The concept of digital competence is being used with increased frequency nowadays: "Given the complexity of this area and the critical importance of the practices involved, it is unsurprising that we find a large number of competing frameworks for describing literacy of the digital age. They have been developed to meet different purposes, out of different theoretical and political perspectives, and use a wide range of terminologies from systems thinking to social science and critical theory" (Beetham, McGill, Littlejohn, 2009, p. 27).

Teachers, pupils and students in Romania now display active interest in using devices such as tablets or laptops owing to their small size and increased storage capacity for information that would occupy large space in printed format. Thus, these computational devices allow visualisation and editing of any type of documents, storage and display of Geography content via multimedia, internet access, including via Geography applications, social networking, and Geography dedicated forums. Therefore, "tablet PCs can also help with adapting instruction and inviting participation. Today's classrooms are becoming fully wireless, which lets teachers harvest and aggregate students' contributions" (Roschelle et al., 2007, p. 39).

The current research aims to investigate the usefulness of tablets and laptops from the perspective of students, starting from the premise that the Ministry of Education and Scientific Research in Romania has manifested the desire to introduce tablets as educational support starting with the preparatory grade in view of gradually replacing printed textbooks: "Romania is at the forefront of countries that are adapting their educational systems to the worldwide trend of using information technology in the teaching and learning process" declared the Minister of National Education and Scientific Research, Remus Pricopie, with the specification that this tendency was confirmed by the new Horizon Report of the European Commission, in partnership with educational technologies experts in the USA (Gheorghiţă, 2014). 


\section{THE USE OF LAPTOP COMPUTERS, TABLETS AND GOOGLE EARTH/GOOGLE MAPS APPLICATIONS DURING GEOGRAPHY CLUB SEMINARS}

In the Romanian educational system there is the perception that the use of applications on tablets and laptops automatically leads to the improvement in the quality of the educational process and to an increased interdisciplinary connection between information acquired during learning. This research also aims to identify the main advantages of replacing classical learning aids with internet connected tablets.

Romanian Geography teachers, pupils and students have Google Earth and Google Maps applications at their disposal. In this study, we shall also analyse the use of Google Earth and Google Maps during Geography classes as "Google Earth lets you fly anywhere to view satellite imagery, maps, terrain, 3D buildings, galaxies in outer space, and the depths of the ocean"1; "Google Maps for Education provides resources to help teachers and students explore, create, and collaborate with mapping tools. Students who are taught Geography are better equipped to understand how human and physical systems interact and to make informed decisions based on that knowledge 2 ."

Google Earth can be defined as a browser or a free interactive geographical tool that enables one to travel to geographical horizons directly from one's PC, tablet or Smartphone with the help of satellite imagery. Operators can see maps, terrain, buildings in three-dimensional format, explore galaxies, planets and ocean depths with the help of this imagery ${ }^{3}$. Thus, images from all over the world are available to anyone who owns a device with an internet connection. The program offers a range of available functions such as visualizing locations, traffic indications, distance measurement, and air flight ${ }^{4}$. Google Maps is an online service specialized in visualizing satellite images of the Earth surface and it displays search functions, orientation tips, 3D visualization, and a "Street View" function allowing ground-level visits of particular locations ${ }^{5}$.

\section{METHOD}

Participants. The research involved 13 students in various gymnasium and high school grades from "Radu Petrescu" High School in Prundu Bîrgăului, attending the Geography Club seminar. The group included 3 pupils from the $5^{\text {th }}$ grade, 2 pupils from the $6^{\text {th }}$ grade, 3 pupils from the $7^{\text {th }}$ grade, 1 pupil from the $8^{\text {th }}$ grade, 3 pupils from the $9^{\text {th }}$ grade and 1 pupil from the $10^{\text {th }}$ grade.

\footnotetext{
${ }^{1}$ https: //plus.google.com/u/0/+GoogleEarth/posts

2 http://maps.google.com/help/maps/education/

3 https://www.google.com/intl/ro/ earth/

${ }^{4}$ https://www.google.com/earth/outreach/tutorials/index.html

${ }^{5}$ https://support.google.com/maps/answer/144349?hl=ro\&ref topic=3092425
} 
Procedure. The research unfolded during the $1^{\text {st }}$ semester of the 2013-2014 school year. The activities took place in the projection hall of the Centre for Information and Research, students being positioned facing the image on display, output from a laptop to a video distribution amplifier.

Operating systems. During the teaching activities we used laptop, tablet and Smartphone operating systems such as Android, Apple or Windows 7. Most frequently, the students' tablets employed the Android operating system. On the laptop computers, Windows 7 and Windows 8 operating systems were used.

The experimental teaching activity unfolded in the following stages:

1. Introducing the Google Earth and Google Maps applications. During the first meetings, we presented the installation of operating systems used on the students' laptops or tablets and the navigation procedures. Students turned the devices on and accessed an internet browser in order to install Google Earth or Google Maps applications.

2. Instruction regarding geographical spaces. We explained to students what the navigation options were, the significance of each element in the application menu and their usage (Fig. 1). Navigation options were to be found on the right side of the program window, the functions of the program were aligned in the menu bar on the upper side of the window, and on the left one might notice the layers of the program where usage and visualization options could be selected.

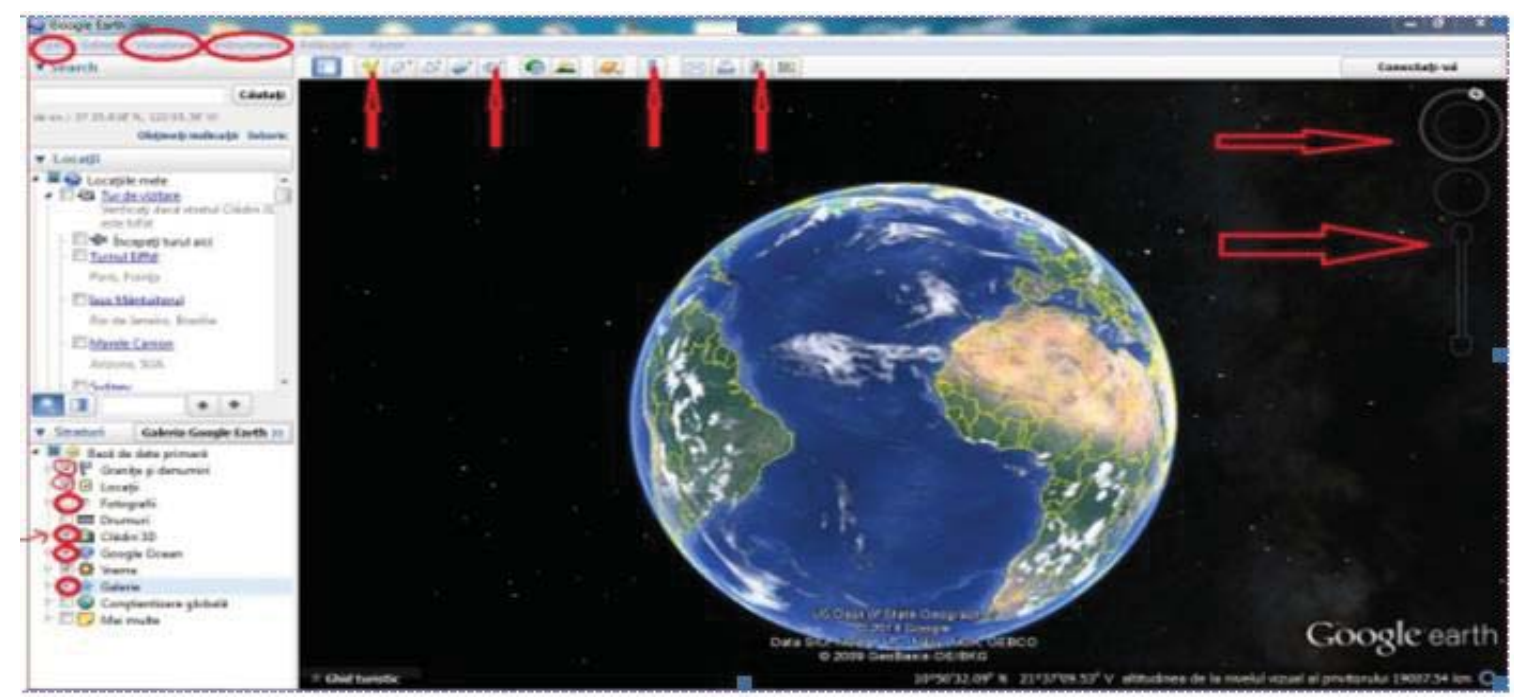

Fig. 1. Explaining the main functions of the Google Earth application (screenshot)

3. Image capturing techniques. Virtual tours. Students learned how to capture geographical images by means of two methods: firstly by saving images with the File menu, secondly by pressing the Save image button on the menu bar, then saving the images as folders for later retrieval and use 
for projects, presentations and others. Students also learned about the Virtual tour option by selecting Take a tour on the menu bar which played recordings of navigations above the area of interest in order to display a virtual tour similar to a film or a video (Fig. 2).

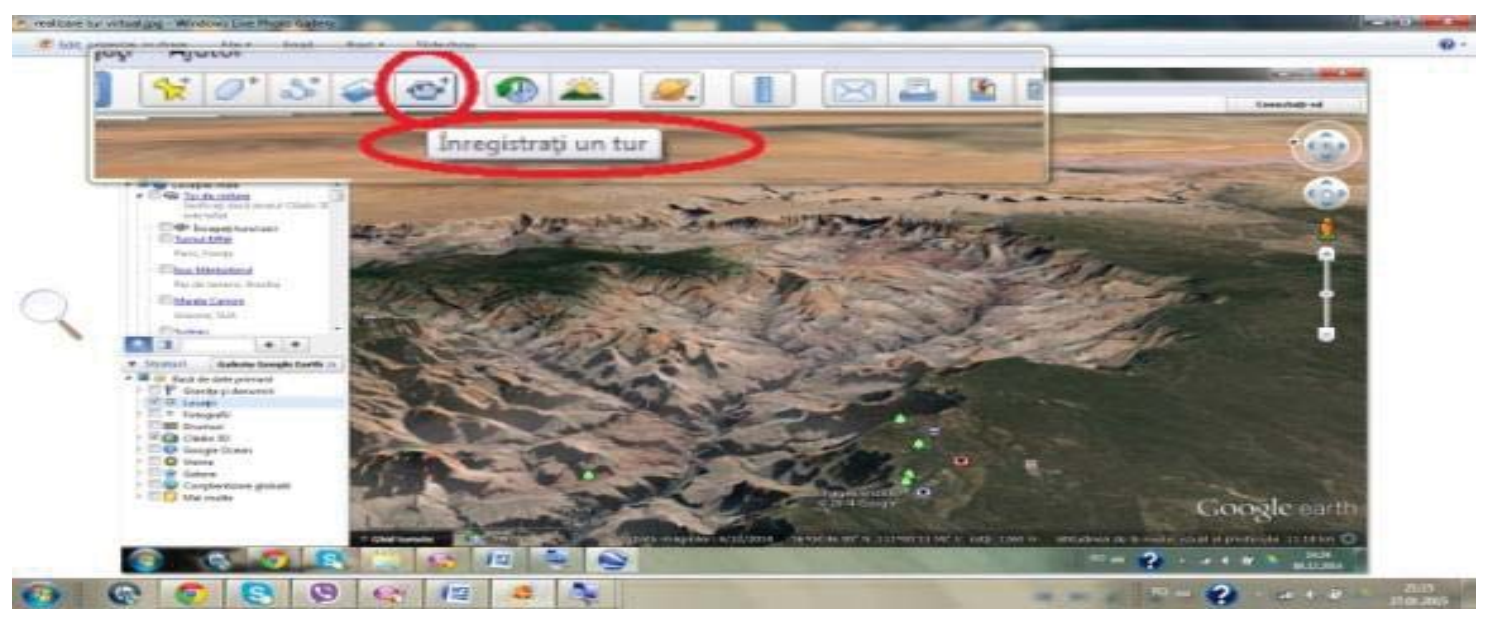

Fig. 2. Explanations on how to take a tour of the Grand Canyon (screenshot)

4. Piloting a virtual tour. With the help of Google Earth, students simulated flights above the Earth's surface by selecting the Flight simulator function from the Tools menu. Thus, they had the opportunity to choose between two types of airplanes and carry out virtual flights above particular areas on the globe, as chosen by each student.

5. Making maps. The teacher explained to students how to create climate maps, demographic maps and other types of maps.

6. Measuring distances, mountain paths and rivers ${ }^{6}$. The teacher explained how to measure the distance between cities and localities, terrain distance between selected points on various tracks that students had actually trekked in the past, the distance between river origin and river influx.

7. Locating geographical oddities. Students looked up the list of places on the Earth where interesting geographical phenomena or processes occurred. Students were assigned the task of locating these places and of creating a virtual tour above the selected area. Location was found by inputting the name of the location or the geographical coordinates in the entry box.

8. Capturing images of natural and man-made disasters. Students accessed internet pages containing information and statistical data about natural and man-made disasters ${ }^{7}$, and then they located the respective

\footnotetext{
${ }^{6}$ https://support.google.com/earth/answer/148072?hl=ro\&ref_topic=4386089

${ }^{7}$ http: // earthobservatory. nasa.gov/NaturalHazards/
} 
areas via Google Earth and Google Maps. They analysed the images and conceived theories concerning the causes of calamities or of disasters based on the images they had analysed.

9. Storing projects in an email address. The images that were captured were sorted in folders, with the names of activities and then uploaded in an email address.

\section{Data collection and analysis}

In order to analyse the usefulness of Google Earth/Maps applications on tablets and laptops during the Geography Club seminars and during Geography classes, we assigned a questionnaire containing 10 questions to the 13 students attending the seminar. For each question, students could choose one answer of the 4 formulated: useless, useful, very useful, I don't know/I don't answer. Beside the four possible answers, students were given the opportunity to provide arguments for the answers they had provided to each question in a few words. We also analysed the manner in which students carried out their assigned tasks as well as each student's electronic portfolio(s).

\section{RESULTS}

In figure 3, we represented the answers provided by our students for the questions in the questionnaire:

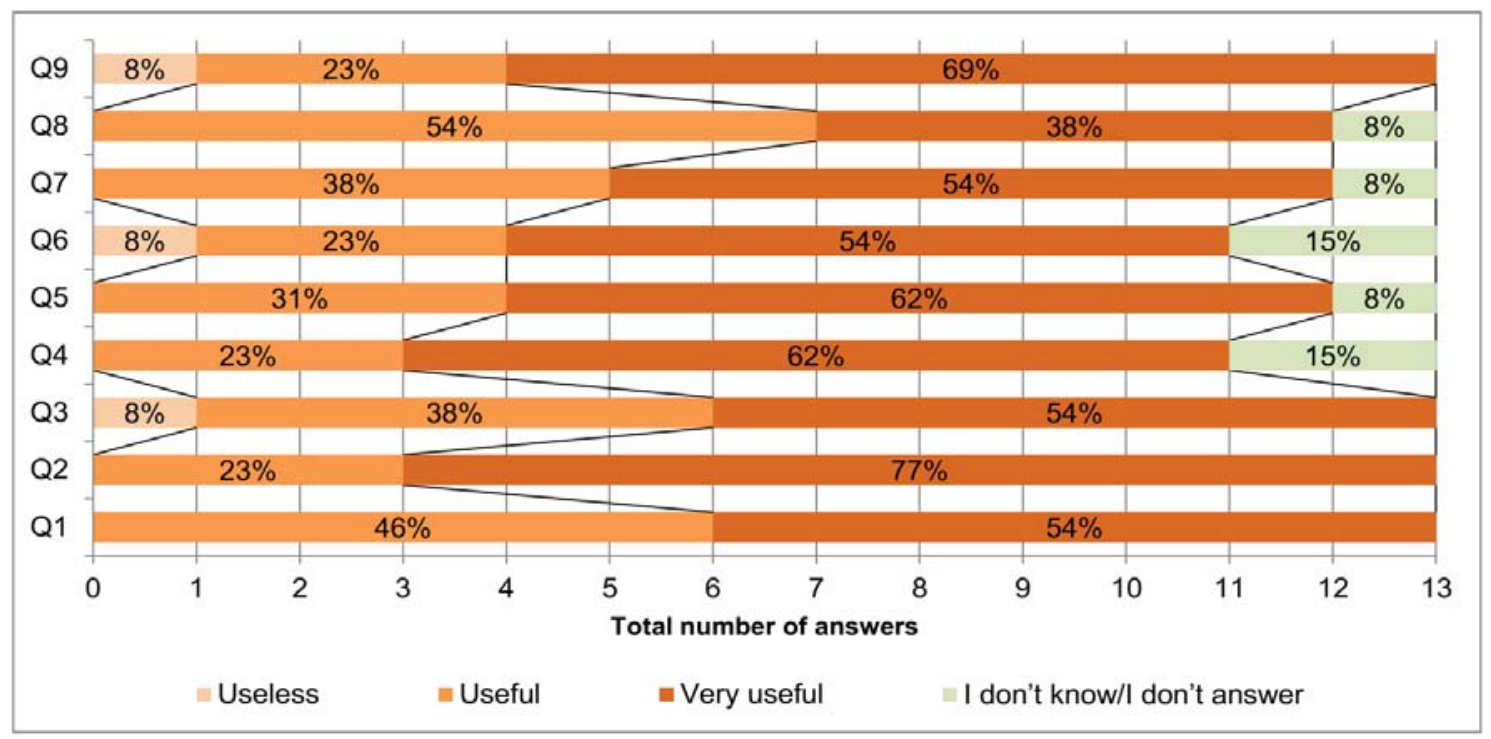

Fig. 3. Students' answers to the questionnaire 
In figure 4, we represented the usefulness of Google Earth and Google Maps applications in the study of Geography, from our students' perspective.

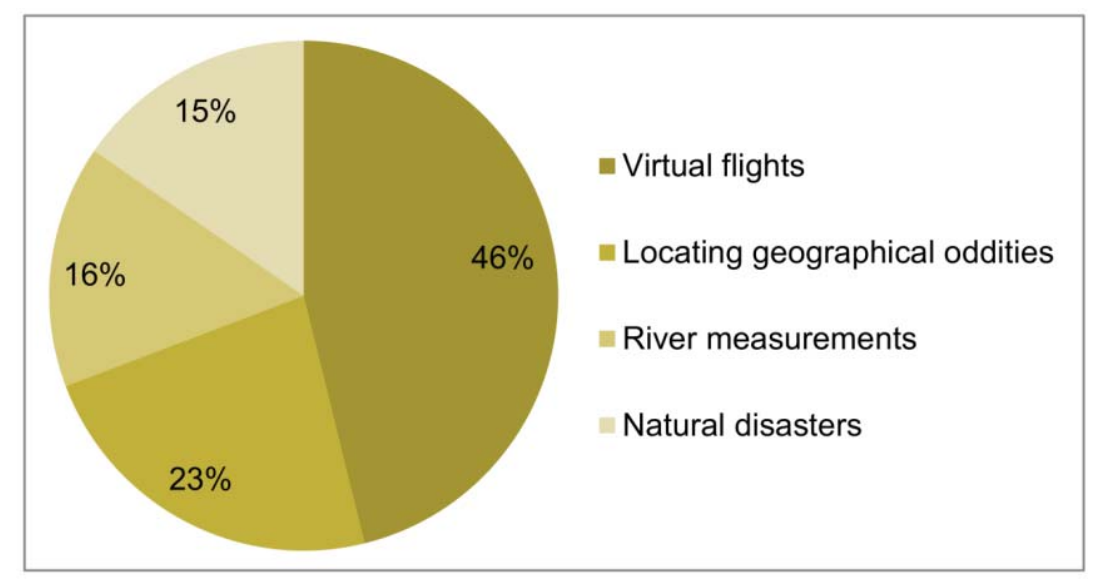

Fig. 4. Usefulness of Google Earth and Google Maps applications in the study of Geography, from students' perspective

\section{DISCUSSIONS}

\section{Analysis of questionnaire answers}

Question 1: "What do you think about the use of tablets/laptops in accessing Google Earth/Maps applications during Geography classes?" 54\% of the students believed laptops and tablets were very useful, $46 \%$ considered them useful, and none of the students considered tablets and laptops useless. All students answered this question. Some of the arguments contained remarkable responses such as: "It is modern and revolutionary"; "Finally, we see something appropriate for our generation". The fact that all students considered the devices and applications very useful and useful during Geography classes indicated their interest in modern technology and interest in learning new things.

Question 2: "How useful are the Google Earth/Maps applications during Geography classes and during Geography Club seminar?" 77\% of the students responded very useful, 23\% responded useful, and there were no students who responded useless or I don't know/I don't answer. Three students commented their options: "It is much easier to search locations with Google Earth as compared to the old map"; "With Google Earth, through the option to visualise via webcam, we were able to see what activities people were doing right at that moment"; "We can better 
understand the meaning of some notions, such as inselberg, moraine, or what volcanoes or icebergs look like."

Question 3: "What is your opinion about replacing paper handwriting with the handwriting function on tablets or on other devices?" $54 \%$ of the students considered this function very useful, $38 \%$ of the students considered it useful for replacing paper handwriting, and $8 \%$ of the students considered it as being useless. Among their arguments, they mentioned: "I can write with ease on the tablet by using this function"; "Storage space on the tablet is considerably larger than on a classical notebook"; "We didn't need to buy notebooks or writing tools". The fact that $92 \%$ of the students appreciated the usefulness of handwriting on tablets is due to the simplification of the writing, deleting or colour choice procedures.

Question 4: "What is your opinion about replacing classical lessons in Geography text books with virtual lessons using Google Earth?" 62\% of the students considered this very useful, $23 \%$ of the students considered it useful, and $15 \%$ of the students did not answer this question. Students supported their views: "Quick retrieval of information", "quick localization of geographical elements". There were no students to consider the virtual lessons useless. The fact that some students did not respond was, we believe, because they did not fully understand the differences between the two types of lesson structure.

Question 5: "What is your opinion about the possibility to take virtual tours anywhere in the world with Google Earth?" $62 \%$ of the students considered it very useful, $31 \%$ deemed it useful and $8 \%$ opted for the response I don't know/I don't answer, but no student considered it to be useless. Among those who appreciated virtual tours to be very useful, two students argued: "Thus we can make films and videos"; "It would be easier for me to watch a virtual tour of Niagara Falls than to read about it and not know what it looks like". We thus discovered that with $. \mathrm{kmz} / . \mathrm{kml}$ files, one can memorize more quickly the details regarding the aspect of some forms of relief, the size of mountains or of other areas.

Question 6: "How useful is the teacher's experience in Google Earth/Maps applications during Geography class activities? 54\% of the students considered the teacher's experience with the applications to be very useful, $23 \%$ deemed it useful, $15 \%$ chose not to respond to this question, and only $8 \%$ considered teacher's experience to be useless. One student mentioned that: "The teacher's experience in knowing these applications is important for us because the teacher must explain some things about every area in which we travel with Google Earth."

Question 7: "How useful are tablets or laptops for the activities unfolding during the Geography Club seminars and during Geography classes when Google Earth/Maps are being used?" $54 \%$ of the students considered them very useful, $38 \%$ responded useful, $8 \%$ of the students did not respond, and no student responded useless. Some students made the following comments: "The tablet and laptop replace the schoolbag and a lot 
of books"; "It is extremely useful because it is the best and the quickest way to search information in case we need it".

Question 8: "How useful are Google Earth/Maps applications in the process of learning and memorizing?" $54 \%$ of the students opted for useful, $38 \%$ of the students considered them very useful, $8 \%$ chose the option $I$ don't know/I don't answer, and no students opted for the answer useless. One student specified: "With Google Maps, I can memorize the places much better than with the old map." Students preferred activities that included virtual learning based on the visualization of static or dynamic images because they facilitated understanding processes and aspects of the Earth's surface and memorised places much quicker as compared to understanding and memorising descriptions presented in texts.

Question 9: "By using Google Earth/Maps applications, we can reduce paper consumption in schools. What is your opinion about that?" $69 \%$ appreciated this aspect as very useful, 23\% believed this to be useful, $8 \%$ of the students opted for useless, and no students responded $I$ don't know $/ I$ don't answer. Students made reference to environmental protection by reducing paper consumption and implicitly deforestation: "The paper used for textbooks and school materials can gradually be replaced by virtual materials"; "Wood consumption will decrease". Responses to this question proved our students' preoccupation for environmental protection, a positive feature of virtual education.

Question 10: "Which of the activities carried out with Google Earth/Maps during the Geography Club seminar did you find to be the most interesting?" $46 \%$ of the students appreciated virtual flights to be the most interesting, 23\% were interested in locating geographical oddities, $16 \%$ were most interested in measuring the Nile and Amazon rivers, and 15\% preferred the activity natural and man-made disasters.

Virtual airplane flights over desert or mountain areas all over the globe were preferred by $46 \%$ of the students because they used some commands that were similar to some computer games. The places in which odd phenomena or processes occurred and could be visualised with the help of satellite imagery aroused great interest and the images were analysed by all our students. As regards natural disasters, students visualised areas in which tidal waves (tsunamis), earthquakes, volcanoes, and landslides occurred. With Google Maps they captured images, assigning each image to a link, then saved and stored the images on an email address.

\section{Analysis of the learning process and of students' results}

Following the activities, we evaluated students' electronic portfolios. They presented their electronic portfolios in folder format. In each portfolio, every student saved images, files, . $\mathrm{kmz} / . \mathrm{kml}$ with virtual tours for each of the activities carried out during the Geography Club seminar, personal 
climate maps, individually designed for particular areas on the globe, length measurements, and forms of relief, images captured via Google Earth or web links to images captured via Google Maps.

In making video materials, students used . kmz/.kml type files, which, according to Google, were defined as "KML, or Keyhole Markup Language. This is an XML file type used for modelling and saving Geographical functions such as points, lines, polygons and models to be displayed in Google Earth, Google Maps And other applications. ${ }^{8}$ Once they were saved, these files directed the operator to a virtual tour around Google Earth. Students practiced the use of the applications by creating these files and then by posting them in a Google database. In the following section, we analysed some of our students' creations.

In Figure 5, we see the journey of a student piloting an airplane. While on this journey, the student observed the forms of relief, the vegetation, the rivers, and the glaciers. We believe that the student needs the explanations of the teacher in order to understand what he/she sees while using this application. For the teacher, it is easier to provide explanations while all students are travelling on the same tour. If every student travels to individual places, it might be impossible for the teacher to provide the necessary explanations simultaneously for them to understand the visualised scenery.

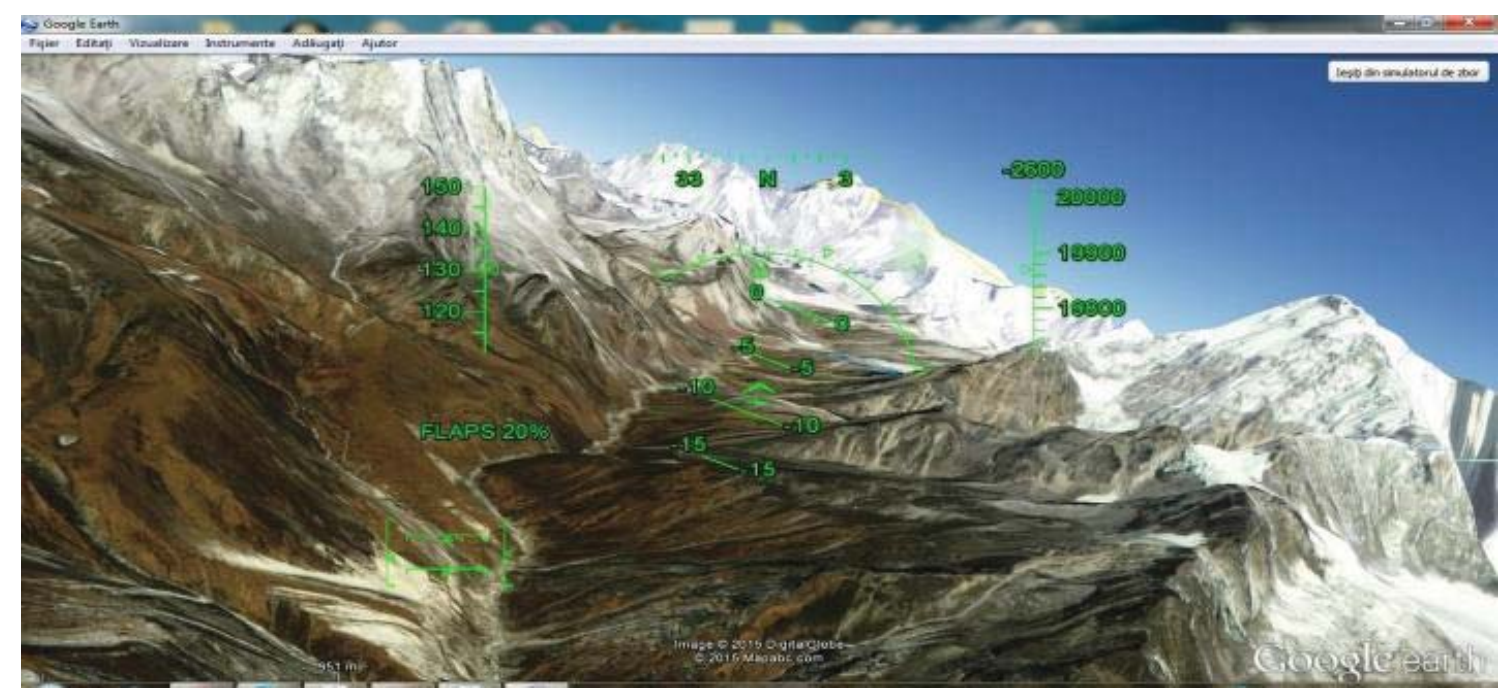

Fig. 5. Piloting an airplane to Mount Everest by a $5^{\text {th }}$ grade student (Google Earth screenshot)

In creating climate maps, our students read a list of types of climate on the globe and the category/place in which each type fitted, and next they set up colours for each climate area. In assigning colours to some

\footnotetext{
${ }^{8}$ https://support. google.com/earth/answer/148118?hl=ro
} 
climate regions with Google Earth, they accessed the Add menu, where they selected the Polygon action, then they drew a contour around the respective region ${ }^{9}$. As can be seen in Figure 6 , the student assigned the colour red to the tropical climate, pink to the sub-tropical climate, and brown to the mountain climate of the Andes. With this application and by solving this task, students learnt new methods of representation for geographical phenomena and they got a better understanding of their spatial distribution.

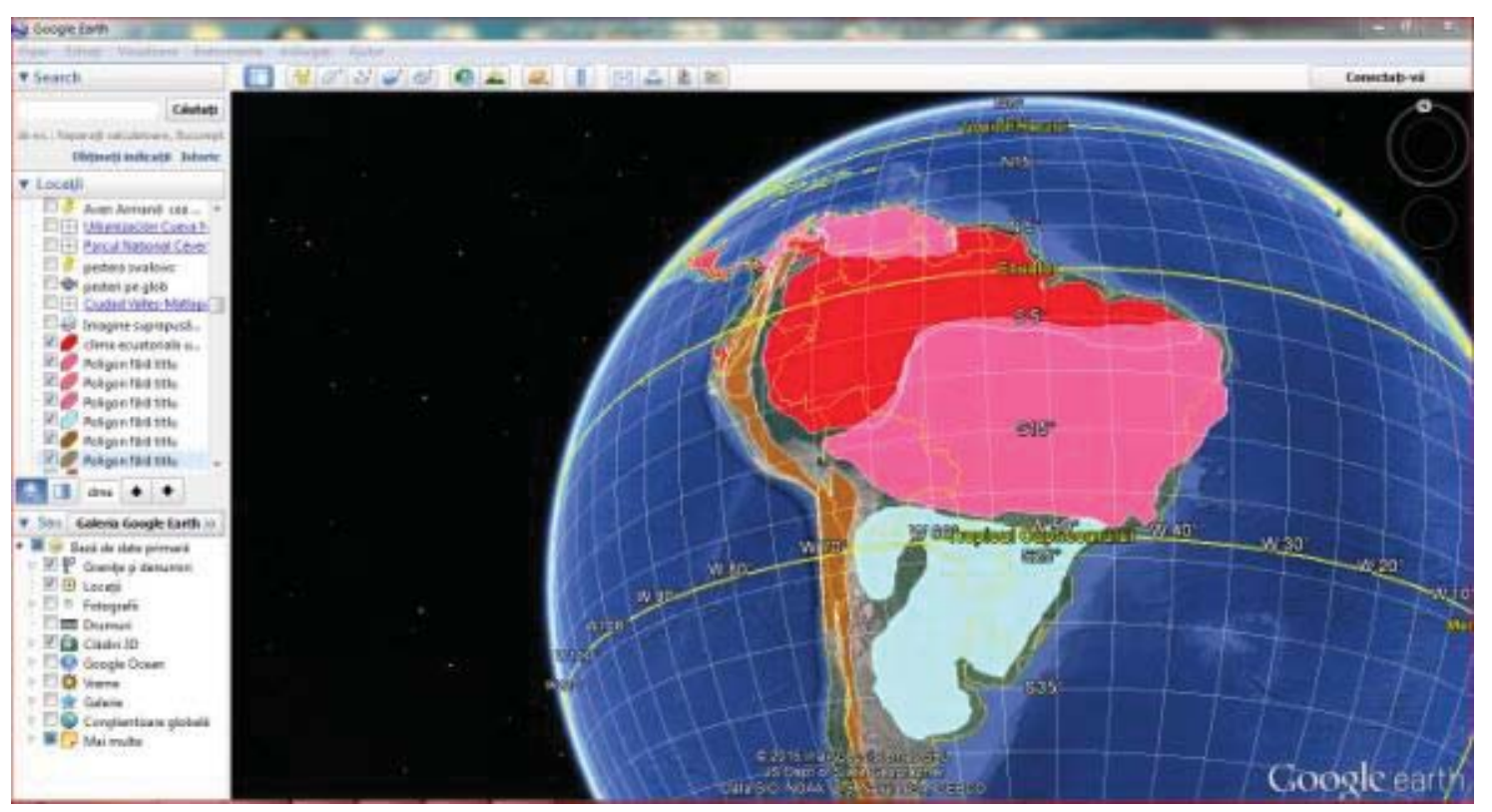

Fig. 6. The climate map of South America made by a $7^{\text {th }}$ grade student (Google Earth screenshot)

In measuring the length of the Amazon River (Figure 7), students consulted various resources about the river $^{10}$ on the internet. In order to measure the length of the river, they placed the cursor on the image of the river source in the region of Mount Nevado Mismi (Peru), then they selected the option Path in the Add menu, at which point the cursor changed shape into an arrow that drew a continuous line on the river stream all the way to the influx. Measuring river lengths on the globe aroused great interest at the beginning of the activity, after which students lost interest because this task required repetitive, monotonous actions.

\footnotetext{
${ }^{9}$ https: // support. google.com/earth/answer/ 148072 ?topic=2376756

10 http://ro.wikipedia.org/wiki/Nevado_Mismi
} 


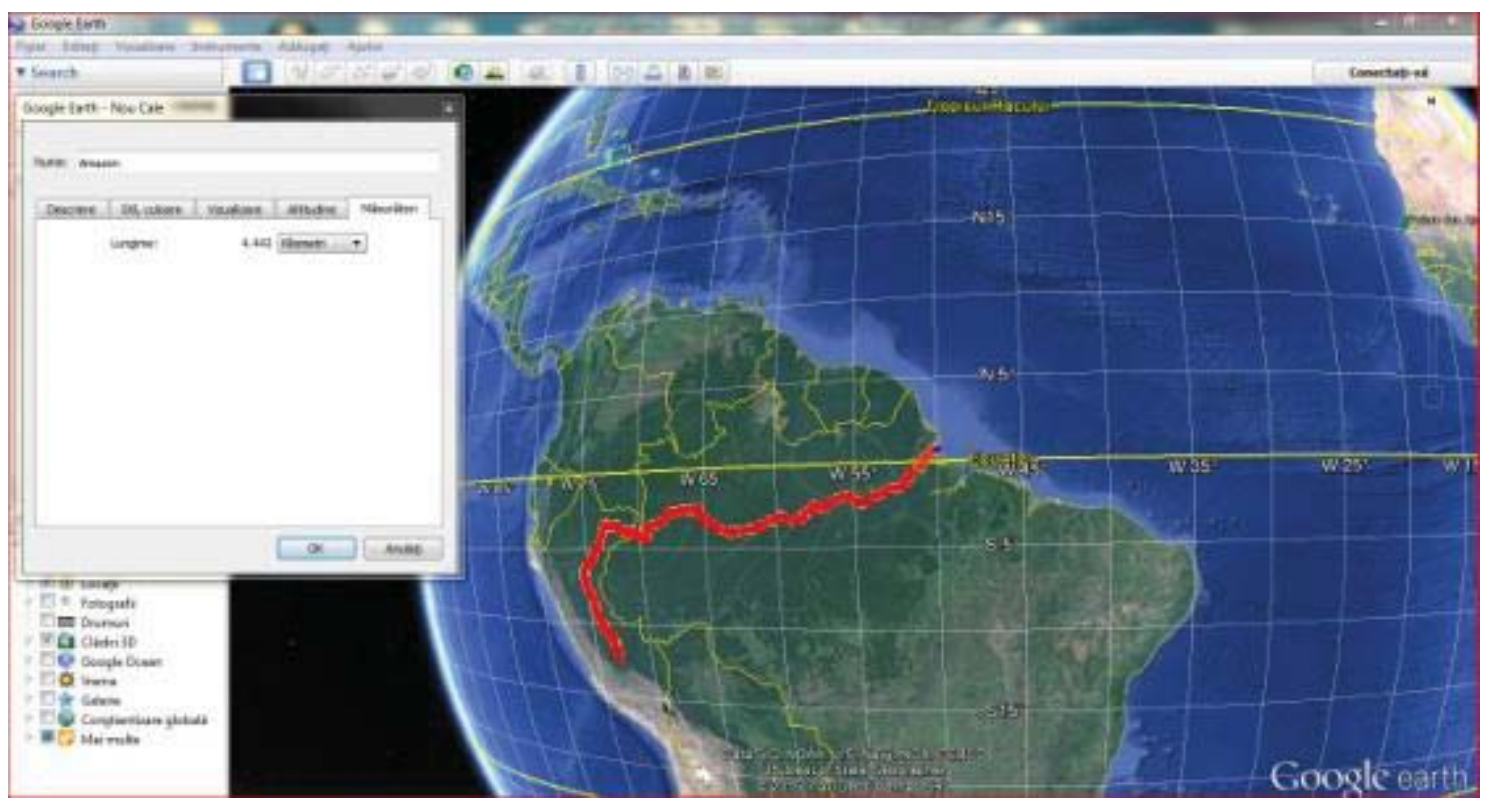

Fig. 7. Measuring the length of the Amazon river stream by a $9^{\text {th }}$ grade student (Google Earth screenshot)

In Figure 8, we notice a student selected Ayers Rock with Google Earth, thus manifesting curiosity about this location. If every other student selects another interesting place on the globe and searches information about it, we have to wonder whether students profoundly understand the formation of that place, the geographical processes taking place, the consequences and relations between environmental components.

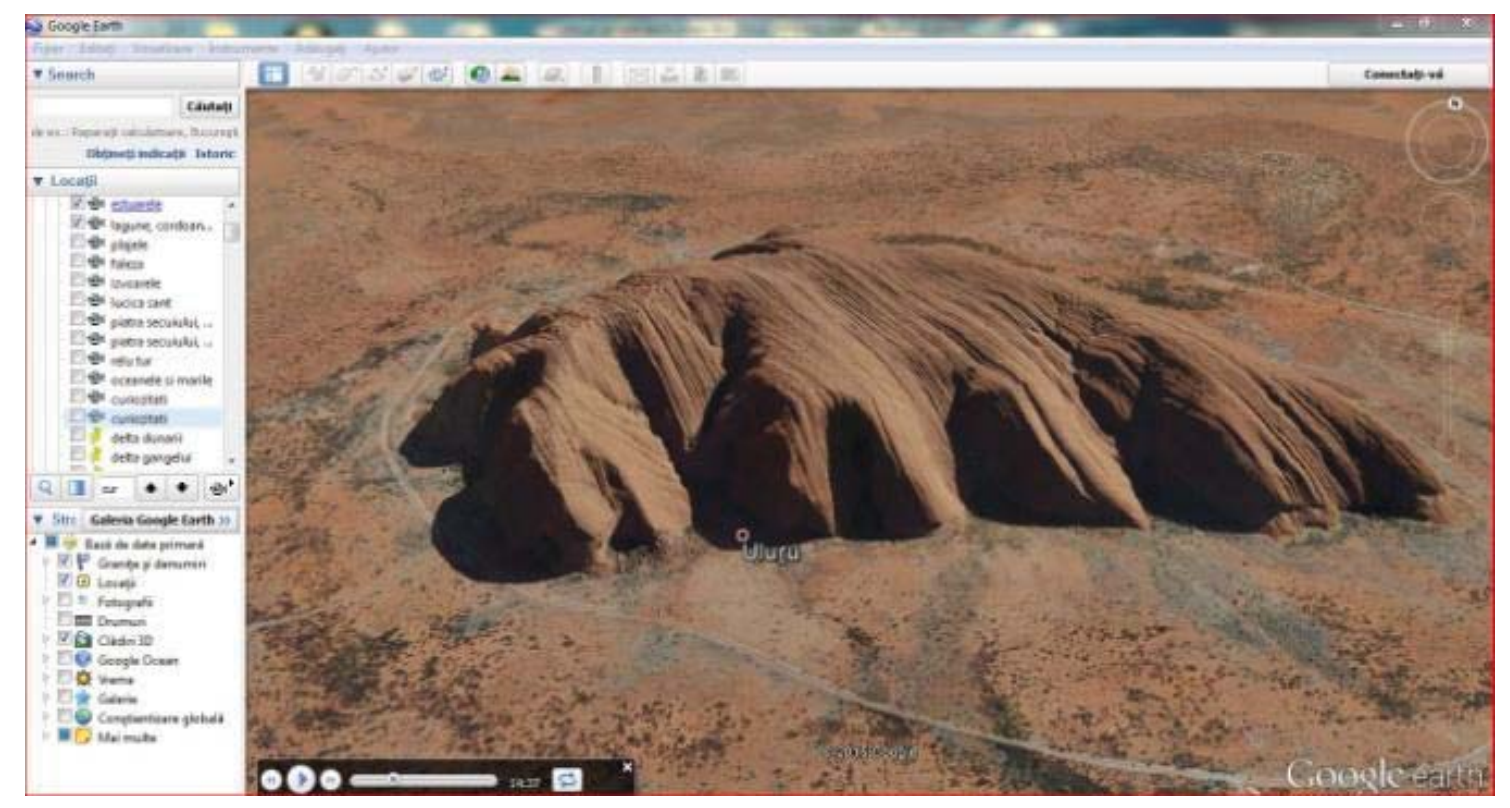

Fig. 8. Ayers Rock, located with Google Earth by an $11^{\text {th }}$ grade student (screenshot) 


\section{THE USE OF LAPTOP COMPUTERS, TABLETS AND GOOGLE EARTH/GOOGLE MAPS APPLICATIONS DURING GEOGRAPHY CLUB SEMINARS}

In Figure 9, we see a student selected Mount Vesuvius using Google Maps. He performed a rotation of the image and analysed the region to get an idea of what might happen in the case of a new volcanic eruption. The student was able to observe and analyse the volcano cone, crater and products of volcanic activity.

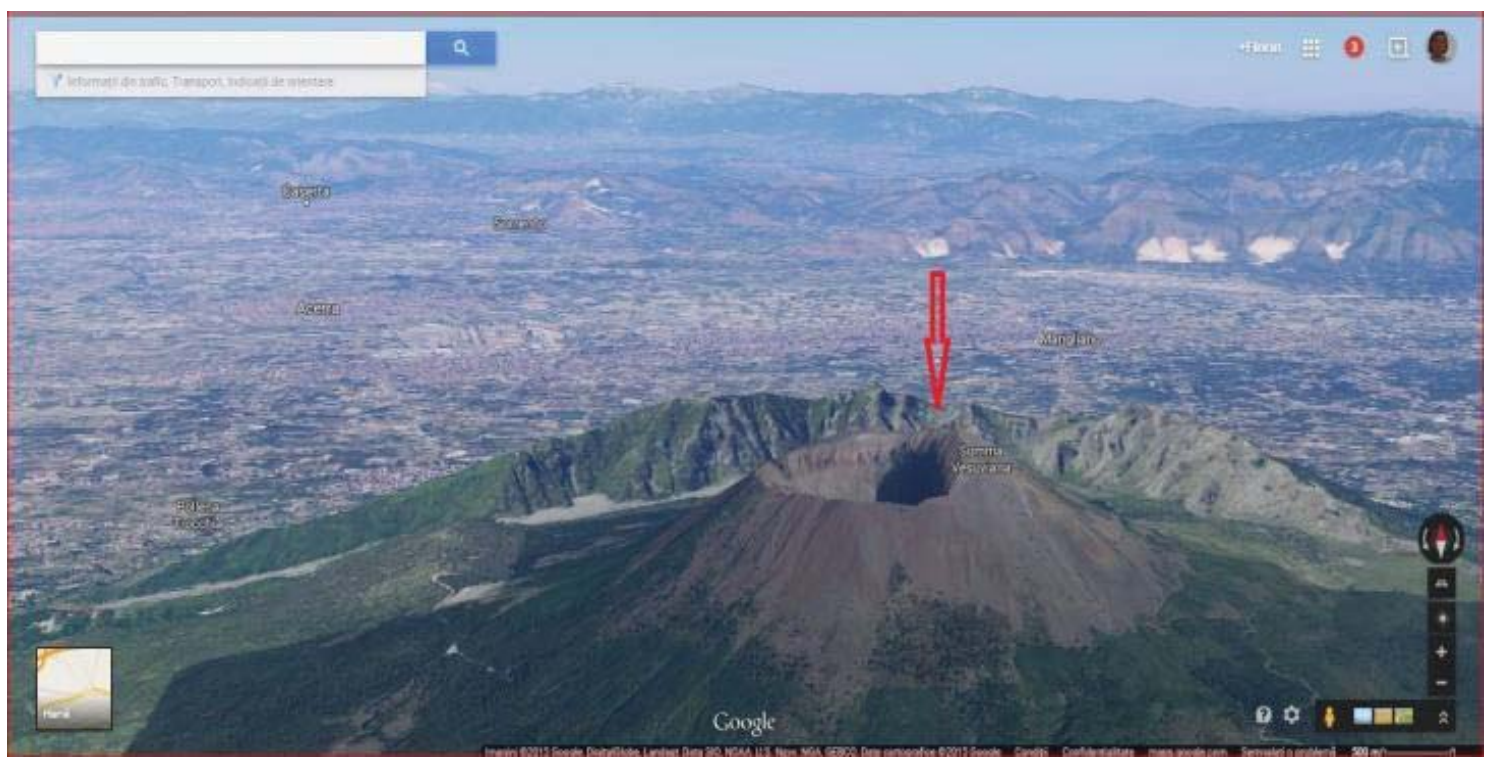

Fig. 9. Mount Vesuvius (Google Maps screenshot)

Despite an obvious increase in technology use to the detriment of traditional teaching tools, by using laptops and tablets, teachers and students alike are faced with challenges that we coped with in this activity ourselves: lack of familiarity with the applications used on tablets; lack of knowledge about options within the operating systems, complexity of commands, internet connection malfunctions. Additionally, constant changes within the software create operating problems both for teachers as well as for students.

Because of faulty internet connection, image clarity was low and additional time was required to retrieve images at high resolution. In order to remedy the situation, the best solution was often to restart devices and apply commands at a slower pace in order to have enough time to run the programs.

In some cases, the activity was disrupted when every student had to navigate Google Earth to locate an image of natural disasters or of geographical oddities, in which case the single wireless connection source displayed difficulty in handling a large number of users. During the virtual tours activity or during the airplane flight activity, students required more time to perform the tasks on account of some slow processor devices. 


\section{CONCLUSIONS}

This research led to a number of conclusions:

Students preferred to use laptop or tablet devices to process information for a number of different reasons: they were easy to carry around and occupied less space; they could get information more quickly as compared to printed sources; they could retrieve and re-access information with ease; they could easily store large volumes of data.

Our students displayed great availability in learning how to use Google Earth and Google Maps applications. They were receptive to the indications provided, manifested curiosity and interest in learning new things, became responsibly involved in the tasks and demonstrated ability in successfully accomplishing tasks by using laptop and tablet devices.

The use of the two applications was appreciated by students because they reached the conclusion that they could get a better understanding of the phenomena and processes occurring on the Earth's surface, that they were forming more accurate representations as compared to simply reading about those phenomena, that they were memorising information more easily and they retained more data if they associated images and performed practical applications as well.

As far as the operating systems employed in the activity were concerned, the most efficient proved to be Android for tablets and Windows for laptops. The technical difficulties that our students faced did not have a negative impact on the overall development of activities. These technical difficulties could be remedied or simply avoided by minimal organizational changes or by resorting to a more recent software version. Protection against information loss was ensured with the Cloud function on each device.

From a financial point of view, the advantages were extensive as the cost of tablet devices were much smaller than the cost of consumable traditional materials used by students for the full length of their educational cycles (four years in secondary school, four years in high school). To ensure the financial support needed to provide the devices necessary for a class activity or for Geography Club seminars, there is the possibility of accessing various financing projects.

\section{References}

Beetham, H., MCGill, L., \& Littlejohn, A. (2009). Thriving in the $21^{\text {st }}$ Century: the Report of the LLiDA Project (Learning Literacies for the Digital Age). Competency Frameworks, Retrieved January 27 2015, from http:// www. caledonianacademy. net/spaces/LLiDA/uploads/Main/reportframe works.pdf 


\section{THE USE OF LAPTOP COMPUTERS, TABLETS AND GOOGLE EARTH/GOOGLE MAPS APPLICATIONS DURING GEOGRAPHY CLUB SEMINARS}

Chou, C. C., Block, L., \& Jesness, R. (2012). A Case Study of Mobile Learning Pilot Project in K-12 Schools. Journal of Educational Technology Development and Exchange 5 (2), pp. 11-26.

Fabian, K., \& Maclean, D. (2014). Keep Taking the Tablets? Assessing the Use of Tablet Devices in Learning and Teaching Activities in the Further Education Sector. Research in Learning Technology, 22.

Gheorghiţă, E. (2014). Pricopie vrea tablete, manuale digitale şi catalog electronic în toate scolile, Retrieved January 12 2015, from http://www. mediafax.ro/social/ pricopie-vrea-tablete- manuale-digitale-sicatalog-electronic-in-toate-scolile- 13440664

Hall, R., Atkins, L., \& Fraser, J. (2014). Defining a Self-evaluation Digital Literacy Framework for Secondary Educators: the DigiLit Leicester Project. Research in Learning Technology, 22.

http://earthobservatory.nasa.gov/ Retrieved January 272015.

http://earthobservatory.nasa.gov/NaturalHazards/ Retrieved J anuary 122015.

http://maps.google.com/help/maps/education/ Retrieved J anuary 152015.

http://maps.google.com/help/maps/education/resources.html Retrieved J anuary 152015.

https://plus.google.com/u/0/+GoogleEarth/posts Retrieved J anuary 152015.

http://ro.wikipedia.org/wiki/Nevado_Mismi Retrieved January 122015.

https://supportgoogle.com/maps/answer/144349?hl=ro\&ref_topic=3092425 Retrieved January 172015.

https://supportgoogle.com/earth/answer/148072?hl=ro\&ref_topic=4386089 Retrieved J anuary 122015.

https://support.google.com/earth/answer/148072?topic=2376756 Retrieved J anuary 182015.

https://support.google.com/maps/answer/144349?hl=en Retrieved J anuary 172015.

https: //support. google.com/earth/answer/148118?hl=ro Retrieved J anuary 172015.

https://www.google.com/earth/outreach/tutorials/index.html Retrieved J anuary 172015.

https://www.google.com/intl/ro/earth/ Retrieved J anuary 172015.

http://www.juicygeography.co.uk/googleearth.htm Retrieved J anuary 242015.

Law on National Education (2011). Law no. 1 on the $5^{\text {th }}$ of January 2011, updated text according to the legislative changes published in Monitorul Oficial al României, Part I, until the $30^{\text {th }}$ of August 2013, Retrieved January 12 2014, from http://www.edu.ro/index.php/base/frontpage

Lisle, R. J. (2006). Google Earth: A New Geological Resource. Geology Today 22 (1), pp. 29-32.

Patterson, T. C. (2007). Google Earth as a (Not Just) Geography Education Tool. Journal of Geography 106 (4), pp. 145-152.

Roschelle, J., Tatar, D., Chaudhury, S. R., Dimitriadis, Y., Patton, C., \& DiGiano, C. (2007). Ink, Improvisation, and Interactive Engagement: Learning with Tablets. IEEE Computer, 40 (9), pp. 42-48, Retrieved January 27 2015, fromhttp://www. researchgate.net/publication/220478387_Ink_Improvisatio n_and_Interactive_Engagement_Learning_with_Tablets 
Sato, H. P., \& Harp, E. L. (2009). Interpretation of Earthquake-induced Landslides Triggered by the 12 May 2008, M7. 9 Wenchuan Earthquake in the Beichuan Area, Sichuan Province, China Using Satellite Imagery and Google Earth. Landslides 6 (2), pp. 153-159.

Sheppard, S. R. J., \& Cizek, P. (2009). The Ethics of Google Earth: Crossing Thresholds from Spatial Data to Landscape Visualisation. Journal of Environmental Management 90 (6), pp. 2102-2117.

Smith, T. M., \& Valliappa L. (2006). Utilizing Google Earth as a GIS Platform for Weather Applications, at 22nd International Conference on Interactive Information Processing Systems for Meteorology, Oceanography, and Hydrology.

Thomas-Brown, K. A. (2011). Teaching for Geographic Literacy: Our Afterschool Geography Club. The Social Studies 102 (5), pp. 181-189.

Whitmeyer, S. J. (ed.) (2012). Google Earth and Virtual Visualizations in Geoscience Education and Research. Geological Society of America, 492. 